\title{
NIH stem-cell guidelines face stormy ride
}

[WASHINGTON] The US National Institutes of Health (NIH) moved a step closer to funding stem-cell research last week. A working group met to refine draft ethical guidelines that scientists would have to obey to meet congressional criteria for the protection of embryos.

The working group deliberated over issues of informed consent, and wrestled with obscure but politically important definitions of words such as 'pluripotent'. But opponents of the research who attended the meeting lambasted the NIH for proceeding on a path that, they claim, contravenes the spirit and the letter of a law that bans federally funded embryo research.

Maggie Wynne, dispatched by the Pro Life Caucus of the House of Representatives, urged NIH director Harold Varmus to reverse his decision to fund the research.

The existing law prohibits funding for research in which embryos are "destroyed [or] discarded", and extracting stem cells from embryos requires their destruction. The Department of Health and Human Services interpreted the law in January as saying that federal funds may finance work on existing stem cells, but not their derivation from embryos, which would have to be financed privately (see Nature 397, 185; 1999). (Stem cells can also be derived from aborted fetuses, which is permissible under federal law.)

At the meeting, the opponents said that recent work may obviate the need to extract stem cells from embryos. This research showed that more specialized stem cells in adult tissues, from brain to bone marrow, can give rise to a variety of tissue types including nerve cells, cartilage, bone and connective tissue.

Richard Doerflinger, of the National Conference of Catholic Bishops, declared that extracting stem cells from embryos may become "irrelevant". He urged the NIH to invest instead in research on adult-derived stem cells for cell and tissue replacement.

Using adult stem cells to derive specialized cells and tissues for therapies would also answer the problem of tissue rejection inherent in use of embryonic stem cells. Provided that the science develops appropriately, an adult could simply have his or her own stem cells harvested and instructed to differentiate into a particular type of tissue; for instance, insulin-producing pancreas cells for a diabetic, or dopamine-producing neurons for a patient with Parkinson's disease.

By contrast, Brigid Hogan, a cell biologist at Vanderbilt University in Tennessee, and a member of the NIH working group, estimated that about 20 immunologically different lines of embryonic stem cells would need to be established for therapies to allow immune compatibility with most of the population.
Shirley Tilghman, a molecular biologist at Princeton University, New Jersey, and cochair of the working group, emphasized that its mandate was to produce guidelines and not to pronounce on whether the government ought to fund stem-cell research. But, given the opposition among anti-abortion groups and their allies on Capitol Hill, the guidelines seem destined to become a political as much as an ethical document.

In the event of a showdown between stem-cell research opponents and supporters in Congress, vacillating politicians being wooed by the promise of the research could point to the guidelines as an assurance that federally funded research would be conducted ethically. But, no matter what the guidelines say, opponents are unlikely to be satisfied by them.

At the heart of the proposed guidelines is the requirement that stem cells be extracted only from embryos left over from fertility treatments. Those doing the extraction either companies or scientists working with private funds - would have to provide to federally funded scientists receiving the cells documentation that the embryos were created for infertility treatment and not for research.

They would also have to guarantee that the woman who donated them did not experience, according to the draft, "undue or even subtle pressure to donate". She must also be informed that commercial products could be developed from the cells, and who would own the products or patents. And the draft forbids the use of stem cells for reproductive cloning and the creation of human-human or human-animal chimeras.

In a separate move, a document released at

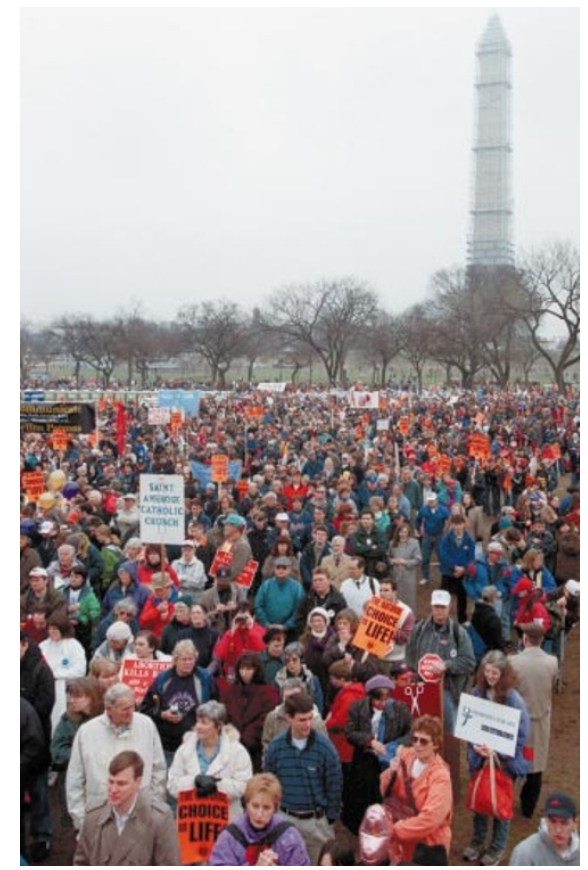

Protests ahead: anti-abortionists, demonstrating in Washington, remain opposed to such research.

the NIH meeting made it appear that President Bill Clinton's National Bioethics Advisory Commission will be more permissive when it makes recommendations on stem-cell research in June. In a letter sent to Varmus by Harold Shapiro, chair of the commission, Shapiro wrote that "we seem to be coming to general agreement" that federal funding should be permitted for both the derivation and research use of stem cells derived from embryos left over from fertility treatments and from aborted fetuses. Meredith Wadman

\section{Cellsale to Elsevier will boost web ventures}

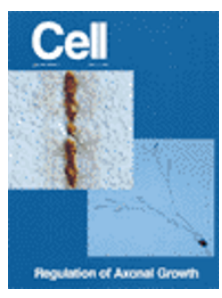

[PARIS] The independent biweekly journal, Cell, previously owned by Benjamin Lewin, has been bought by the Dutch company Elsevier Science, in a strategic move that the company says is aimed at consolidating its electronic publishing activities in life sciences.

Lewin will remain as editor-in-chief, following the purchase of Cell Press whose other titles are Molecular Cell, Immunity and Neuron - according to Geert Noorman, managing director of Elsevier Science's Life Sciences Division.

"Cell Press will stay as an independent brand with the same editorial policy," says Noorman. "Why change a winning team?"

He adds that the primary motivation behind Elsevier Science's move was the desire to acquire a flagship journal for Elsevier's electronic publishing activities. The deal will provide Cell Press with the infrastructure to allow it to develop its electronic activities, he says.

By combining the brand names of Cell Press with the large range of Elsevier Science journals in life sciences, the company hopes to become one of the "first-stop shops" for scientific information on the web, says Noorman. "It's the battle of the bookmarks."

The company has not given any financial details of the deal, but the sum paid is widely believed to have been in excess of US\$100 million.

Cell was set up in 1974 by the Massachusetts Institute of Technology with Lewin - previously a senior editor at Nature - as its editor. The magazine was subequently bought by Lewin and has been owned by him ever since.
Declan Butler 